\title{
AIRBORNE BIRCH POLLEN IN POLAND AND LATVIA IN THE LIGHT OF DATA OBTAINED FROM AEROBIOLOGICAL MONITORING AND TAUBER TRAPS IN RELATION TO MEAN AIR TEMPERATURE
}

\author{
Irena Agnieszka Pidek ${ }^{1}$, Krystyna Piotrowska² ${ }^{2}$ Bogusław Michał Kaszewski \\ Laimdota Kalnina ${ }^{3}$, Elżbieta Weryszko-Chmielewska ${ }^{2}$ \\ ${ }^{1}$ Institute of Earth Sciences, University of Maria Curie-Skłodowska, al. Kraśnicka 2 c/d, 20-718 Lublin, Poland \\ ${ }^{2}$ Department of Botany, University of Life Sciences, Akademicka 15, 20-095 Lublin, Poland \\ ${ }^{3}$ Faculty of Geography and Earth Sciences, University of Latvia, 19 Rainis Blvd., Riga LV-1586, Latvia \\ e-mail: ipidek@poczta.umcs.lublin.pl
}

Received: 10.08.2009

\section{Abstract}

Birch pollen contains allergens belonging to those with the strongest allergenic properties. In order to trace pollen season patterns of this taxon and pollen annual sums at a wider regional scale, cooperation was established with the University of Latvia in Riga (Latvia). A comparison of the results obtained in the years 2003-2008 in Lublin and in Riga, using volumetric samplers, shows that there was a similar trend in the abundance of birch pollen. The highest sums were noted at both sites in 2003. In all the study years, more birch pollen grains were recorded in Lublin than in Riga, on the average by 7110 . The birch pollen seasons started earlier in Lublin than in Riga, on the average by 6 days, and they ended earlier in Lublin, on the average by 18 days. In Riga the birch pollen seasons were longer and less abundant than in Lublin. In addition, in both the regions, i.e. in SE Poland (the Roztocze area) and in Latvia (the area of Marupe near Riga, Taurene, Teici and Rucava), there is pollen data series available obtained from annual pollen deposition monitoring conducted using the modified Tauber traps. These pollen counts have been carried out under the Pollen Monitoring Programme (http://pmp.oulu.fi) since 1998. The 11year data series in Roztocze and the 10-year data series in Latvia allowed the trends in the occurrence of years of abundant or poor birch pollen release to be traced. In Roztocze maximum Betula pollen deposition occurred in the year 2003, in Latvia - in 1999. The absence of a significant correlation between SE Poland and Latvia with regard to the trends in the occurrence of years of abundant $\mathrm{Be}$ tula pollen deposition induced the authors to seek climatic factors responsible for increased birch pollen production. The analysis of the Spearman's rank correlation coefficients between annual Betula pollen sums in Roztocze and mean air temperature in June, July and August in the year preceding pollen emission as well as in spring (January-April) of the year of pollen emission showed a statistically significant negative correlation with air temperature in February of the year of pollen emission.

Key words: Betula, pollen monitoring, volumetric method, Tauber traps, Lublin, Roztocze, Riga

\section{INTRODUCTION}

Birch pollen contains the allergens Bet $v 1$, Bet $\mathrm{v} 2$ and Bet v 4, belonging to those with the strongest allergenic properties (R o s s i et al. 2003), and that is why this taxon is an object of special interest on the part of aerobiologists. E m b e r l in et al. (1997) note that over the recent years both the earlier start of the Betula pollen season and increased pollen production of this taxon have been observed. In order to predict earlier the pattern and intensity of pollen shedding, in Sweden an attempt was made to create a model (D a h 1 and S trandhede, 1996) which would be useful in pollen allergy prevention.

The alternate occurrence of years of abundant and poor birch pollen emission is generally observed (Emberlin et al. 1993; Spieksma et al. 1995; Corden et al. 2000), and the existence of a biennial rhythm of pollen release is even suggested (L a ta 1 ow a et al. 2002). This phenomenon is associated with the natural rhythm of the alternate production of an abundant amount of flowers in one year and the growth of vegetative organs in the next year (S p i e k s m a et al. 2003), but it also depends on weather factors both in the period of pollen production in anthers and during their release into the atmosphere (L a ta $\nmid$ ow a et al. 2002).

The determination of pollen abundance is generally made indirectly by measuring the concentration of birch pollen grains per $\mathrm{m}^{3}$ of air sucked into by volumetric samplers or pollen deposition per unit area using all year round Tauber traps in different modifications, placed at ground level, or Durham samplers, Petri dishes, jars and other types of simple pollen-capturing devices. Tauber traps are 
commonly used in Europe under the Pollen Monitoring Programme (PMP - http://www.pmp.oulu. fi) - an international project designed to measure modern pollen deposition of taxa important from the point of view of paleoecological interpretations in regions varied in terms of their vegetation and climate. Other types of samplers operating based on the gravimetric method are rarely used due to the poor possibilities of comparing results.

Nevertheless, it has been demonstrated several times, in spite of essential differences in pollen capture methodology, that the results of pollen counts made using Tauber traps and the volumetric method are well correlated both at a local scale, i.e. when both types of the trap are placed at the same site (Le vetin et al. 2000; $\mathrm{R}$ an t a et al. 2007), and at a regional scale when the sites are distant from each other $(\mathrm{Pidek}$ et al. 2006; 2008). In the case of these two different methods, a comparison of the trends in pollen annual sums yielded good results ( $\mathrm{R}$ a n t a et al. 2007).

The aim of the present study was to trace pollen season patterns and annual sums of Betula pollen at wider regional scale in Poland and Latvia. Annual pollen sums were analysed in relation to thermal data originating from the meteorological stations closest to the pollen monitoring sites. Due to the fact that birch pollen dispersal, which occurs in the period April/May, is affected not only by the weather in the spring of the year of pollen emission, but also by the weather in the summer in the year preceding flowering, since birch inflorescences start to develop in June of the previous year (S u s zka, 1979), mean monthly air temperature in the periods June-August of the preceding year and January-April of the year of pollen emission was analysed.

\section{MATERIALS AND METHODS}

In order to trace pollen season patterns and birch annual sums at a wider regional scale, cooperation was established with the University of Latvia in Riga, where pollen counts have been carried out using a Burkard volumetric sampler since 2003, whereas the pollen data series obtained from the Tauber traps in the area of Taurene, Teici Mire, Rucava and Marupe is 10 years long (1998-2007). In the present study, an analysis of the Betula pollen seasons in Poland (Lublin) and in Latvia (Riga) was performed based on the data obtained from pollen counts carried out using the Lanzoni VPPS 2000 volumetric sampler (Lublin) and the Burkard volumetric sampler (Riga), as well as annual Betula pollen sums in Lublin and in the Roztocze region were compared. In the same way, annual Betula pollen sums in Riga and in the most adjacent PMP trap site in Marupe were compared. The distribution of research sites is shown in Fig. 1.

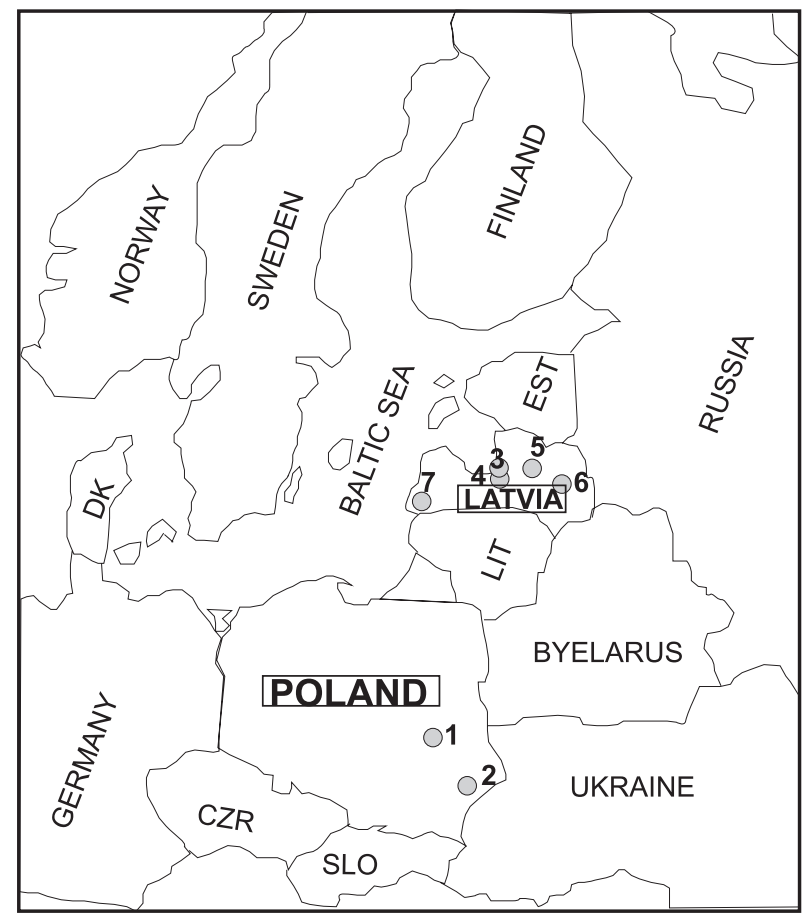

Fig. 1. Location of the pollen monitoring sites in Poland and Latvia.

Explanations to abbreviations and numbers: DK-Danish Kingdom; CZR-Czech Republic; SLO-Slovakia; LIT-Lithuania; EST - Estonia; numbers: 1 - Lublin town; 2 - Guciów village in the Roztocze; 3 -Riga town; 4 - Marupe; 5 - Taurene; 6-Teici; 7 - Rucava. 
Both regions differ in terms of climatic conditions. The stations in question (Zwierzyniec, Lublin, Riga) are situated in the temperate climate zone, transitional between the maritime and continental climates (M a rty n, 2000).

The annual number of sunny hours changes from approx. 1550 in Lublin to 1815 in Riga, but during the year this number undergoes large changes, primarily due to varying day length during the year. In Riga monthly sunshine duration in December is 25 hours, and in June ca. 280 hours (M a r t y n , 2000). In Lublin these values are, respectively: $32 \mathrm{~h}$ and $220 \mathrm{~h}$ (K a s z e w s k i , 2008). The distribution of total solar radiation is slightly different, since its higher values (3700-3800 MJ/m²) occur in Lublin and Zwierzyniec, whereas in Riga it is only approx. $3400 \mathrm{MJ} / \mathrm{m}^{2}$ (M a r ty n, 2000; K a s z e w s ki , 2008).

Atmospheric circulation, being responsible for the transport of air masses from the Atlantic Ocean and Western Europe in particular during the cold period of the year, plays a much greater role in shaping the climate of the cities concerned. The influence of the Baltic Sea on the climate of western Latvia (Riga) is not very large (M a r t y n, 2000).

Table 1

Annual air temperature patterns in Zwierzyniec, Lublin and Riga in the years 1998-2007.

\begin{tabular}{|c|c|c|c|c|c|c|c|c|c|c|c|c|c|}
\hline & I & II & III & IV & V & VI & VII & VIII & IX & $\mathrm{X}$ & XI & XII & Year \\
\hline Zwierzyniec & $-2,2$ & $-1,3$ & 1,8 & 8,3 & 13,5 & 16,8 & 18,9 & 17,3 & 11,7 & 8,1 & 2,9 & $-1,4$ & 7,9 \\
\hline Lublin & $-1,2$ & $-0,3$ & 3,2 & 10,0 & 15,0 & 18,1 & 20,3 & 19,1 & 14,1 & 9,4 & 3,7 & $-0,4$ & 9,3 \\
\hline Riga & $-1,9$ & $-2,5$ & 0,8 & 7,2 & 12,0 & 15,9 & 19,0 & 17,7 & 13,0 & 7,6 & 2,3 & $-0,6$ & 7,5 \\
\hline
\end{tabular}

Among the stations in question, Lublin is characterised by the highest mean annual temperature $\left(9.3^{\circ} \mathrm{C}\right)$, and Riga by the lowest $\left(7.5^{\circ} \mathrm{C}\right)(\mathrm{Tab} .1)$. In the annual pattern, minimum temperature occurs in Lublin and Zwierzyniec in January, whereas in Riga in February, which may be attributable to the impact of the sea. This impact also manifests itself in the fact that mean spring temperature (March-May) in Riga is lower than in autumn (respectively: $6.6^{\circ} \mathrm{C}$ and $7.6^{\circ} \mathrm{C}$ ). In Lublin and Zwierzyniec mean spring temperature is slightly higher than autumn temperature.

Annual total precipitation in Riga and in Lublin is similar, and it is 570 and $550 \mathrm{~mm}$, respectively (K a s z ewski , 2008; M arty n, 2000). Higher precipitation, above $700 \mathrm{~mm}$, occurs in Zwierzyniec, which results mainly from the location of the station in the Roztocze region that is a barrier in the way of air masses transported from the south-west and west. The number of days with precipitation $\geq 0.1 \mathrm{~mm}$ is the highest in Riga (approx. 180), and the lowest in Lublin (approx. 160).

\section{Pollen data \\ Poland}

In the Roztocze region, a pollen deposition study was carried out in the area of the village of Guciów, based on traps placed in open landscape and in different forest communities. A standard method was used developed under the Pollen Monitoring Programme, which involves the capture of the whole annual plant pollen influx in Tauber traps (T a uber, 1974; H i ck s and Hy väri n en, 1986), and subsequently the pollen material is subjected to laboratory treatment using Lycopodium marker tablets and to microscopic analysis (H i c k s et al. 1996; 1999). The PMP method allows the calculation of the number of pollen grains of a particular taxon deposited per $\mathrm{cm}^{2}$ of surface area in a given year.

In Lublin pollen counts were made by the volumetric method using a Lanzoni VPPS 2000 pollen sampler, which was located in the Śródmieście (centre of town) district at a height of $18 \mathrm{~m}$. Betula pollen total per $\mathrm{m}^{3}$ of air was determined within a year. The onset and the end of the pollen season were determined using the $98 \%$ method, according to which the start of the pollen season is on the day when $1 \%$ of the cumulative sum of Betula pollen is recorded and the end when $99 \%$ of pollen is found ( $\mathrm{E} \mathrm{m} \mathrm{berlin} \mathrm{et} \mathrm{al.} \mathrm{1993).}$

\section{Latvia}

In Riga measurements of airborne pollen concentrations were made using a Burkard sampler placed on the roof of the main building of the University of Latvia, at a height of $23 \mathrm{~m}$ above ground level.

Pollen monitoring using Tauber traps in accordance with the PMP guidelines was carried out since 1998 in the area of the localities of Taurene and Teici in central Latvia, Rucava - in south-western Latvia as well as in Marupe near Riga. The closest distance between the Burkard sampler in Riga and the Tauber 
traps in Marupe was $15 \mathrm{~km}$ and therefore the data from this sampling site were selected for comparison with the data from Riga. lysed:

In the present study, the following were ana-

1) birch pollen season patterns in Lublin and in Riga as well as annual pollen sums obtained using the volumetric method.

2) annual Betula pollen sums obtained in the Tauber traps in Poland (Roztocze) over a period of 11 years (1998-2008) and in Latvia (in four regions, i.e. Taurene, Teici, Rucava and Marupe) over a period of 10 years (1998-2007), and the occurrence of years of abundant and poor deposition was traced.

3) eight-year (2001-2008) fluctuations in annual Betula pollen sum in Roztocze and in Lublin as well as six-year (2003-2008) data on annual Betula pollen sums in Riga and at the closest PMP sampling site, i.e. Marupe 2.

To compare the trends in annual sums of Betula pollen deposited per ground surface area (Tauber traps) and captured by the volumetric samplers, the percentage pollen index was used. This indicator demonstrates what portion of the total sum from several monitoring years is the sum from a particular year and it has already been used to compare monitoring results obtained by both methods (i.e. the volumetric and PMP methods - vide Pid e k et al. 2006; 2008).

The percentage pollen index (PI) was calculated in accordance with the following formula:

$\mathrm{PI}=$ annual pollen sum in a particular year / annual pollen sum within the respective period $\mathrm{x}$ number of monitoring years

In the case of the PMP method, the mean sum of pollen grains, deposited per $\mathrm{cm}^{2}$ of surface area, obtained based on the results from trap sites of supralocal importance located in open landscape or in large openings with a diameter of 80-100 m, was accepted as the annual pollen sum in a particular year. In Roztocze four such sites were taken into account (Traps: 4, 6, 7 and 8). The trends in annual sums at particular sites were also analysed in order to find out to what degree they were in agreement with the trends revealed by the averaged sums from these four sites in the respective study year. In Latvia four sites were also taken into account, although unlike Roztocze, they are located in the parts of the country distant from each other and with significantly differing vegetation types (Taurene 1, Rucava 1, Teici Mire 2 and Marupe 2).

Table 2

Description of the Pollen Monitoring Programme sites in Latvia and Poland.

\begin{tabular}{|c|c|c|c|c|}
\hline Site code & Latitude, $\mathrm{N}$ & Longitude, E & $\begin{array}{l}\text { Eleva-tion } \mathrm{m} \\
\text { a.s.l. }\end{array}$ & Landscape, prevailing vegetation \\
\hline \multicolumn{5}{|c|}{ LATVIA } \\
\hline $\begin{array}{l}\text { LV/LK/Tau } 1 \\
\text { Taurene } 1\end{array}$ & $57^{\circ} 10^{\prime} 15^{\prime \prime}$ & $25^{\circ} 41^{\prime} 31^{\prime \prime}$ & 189 & open, top of hill \\
\hline $\begin{array}{l}\text { LV/LK/Ru1 } \\
\text { Rucava } 1\end{array}$ & $56^{\circ} 12^{\prime} 19^{\prime \prime}$ & $21^{\circ} 05^{\prime} 11^{\prime \prime}$ & 15.7 & $\begin{array}{l}\text { pine forest } \\
\text { partly open }\end{array}$ \\
\hline $\begin{array}{l}\text { LV/LK/Tei2 } \\
\text { Teici Mire } 2\end{array}$ & $56^{\circ} 35^{\prime} 10^{\prime \prime}$ & $26^{\circ} 28^{\prime} 11^{\prime \prime}$ & 106 & open raised bog, close to edge \\
\hline $\begin{array}{l}\mathrm{LV} / \mathrm{LK} / \mathrm{MA} 2 \\
\text { Marupe } 2\end{array}$ & $56^{\circ} 57^{\prime} 14^{\prime \prime}$ & $24^{\circ} 06^{\prime} 00^{\prime \prime}$ & 10 & forest close to city \\
\hline \multicolumn{5}{|c|}{ POLAND } \\
\hline Trap 4 & $50^{\circ} 35^{\prime} 04,1^{\prime}$, & $23^{\circ} 03^{\prime} 27,6^{\prime \prime}$ & 247 & $\begin{array}{l}\text { large clearing within mixed pine } \\
\text {-birch forest with admixture of other } \\
\text { tree species }\end{array}$ \\
\hline Trap 6 & $50^{0} 34^{\prime} 55,7^{\prime}$, & $23^{\circ} 04^{\prime} 00,1^{\prime \prime}$ & 305 & \\
\hline Trap 7 & $50^{0} 34^{\prime} 57,4^{\prime \prime}$ & $23^{\circ} 04^{\prime} 24,9^{\prime}$ & 246 & $\begin{array}{l}\text { Open vegetation - abandoned field } \\
\text { overgrowing by birch and willow }\end{array}$ \\
\hline Trap 8 & $50^{0} 34^{\prime} 21,2{ }^{\prime}$, & $23^{\circ} 03^{\prime} 14,1^{\prime}$, & 348 & large clearing within beech forest \\
\hline
\end{tabular}




\section{Meteorological data}

The Spearman's rank correlation coefficient $\left(\mathrm{r}_{\mathrm{s}}\right)$ was used to evaluate the effect of air temperature and precipitation on the abundance of Betula pollen,

$$
r_{S}=1-\frac{6 \sum D^{2}}{N\left(N^{2}-1\right)}
$$

where: $\Sigma \mathrm{D}^{2}-$ the sum of squares of differences between the ranks, $\mathrm{N}$ - the number of pairs of measurements.

This coefficient is used in the so-called small samples where the number of pairs of measurements (i.e. $\mathrm{N}$ ) is less than 30 , and there is no assumption of the normality of distribution and linearity between two variables (Ł o m n i cki, 1995).

Spearman correlation coefficients of correlation were calculated between the birch pollen sum in a particular year and mean monthly air temperature in June, July and August in the year preceding pollen emission as well as in the period from January to April in the year of pollen emission.

The data on air temperature came from the meteorological observatories closest to the pollen monitoring sites. In the case of Lublin, it was the Meteorological Observatory of the Meteorology and Climatology Department, the Maria Curie-Skłodowska University in Lublin (Poland), located in the city centre in a treecovered city centre square $\left(\varphi=51^{\circ} 15^{\prime} \mathrm{N} ; \lambda=22^{\circ} 34^{\prime}\right.$ $\mathrm{E} ; \mathrm{H}=195.3 \mathrm{~m}$ a.s.l.). In Roztocze thermal data were used from the Meteorological Station of the Roztocze National Park in Zwierzyniec $\left(\varphi=50^{\circ} 37^{\prime} \mathrm{N} ; \lambda=22^{\circ}\right.$ $58^{\prime} \mathrm{E} ; \mathrm{H}=230 \mathrm{~m}$ a.s.1.), located at a distance of about $7 \mathrm{~km}$ from the trap sites in question placed in the area of Guciów. In the case of Lublin, meteorological data for the years 2000-2008 were used, and in the case of Zwierzyniec, data for the years 1998-2008. The Tauber traps in Roztocze are situated ca $120 \mathrm{~km}$ from Lublin volumetric sampler.

For correlation with the pollen monitoring sites in Riga ( $\varphi=56^{\circ} 58^{\prime} \mathrm{N} ; \lambda=24^{\circ} 03^{\prime} \mathrm{E}$; $\mathrm{H}=7 \mathrm{~m}$ a.s.l.), temperature data from the meteorological station located in the city centre were used, which are available on the TuTiempo website (http://www.tutiempo.net/ clima/).

\section{RESULTS}

\section{Pollen data}

Pollen season patterns in Lublin and in Riga

In Poland and Latvia birch belongs to taxa which reach the highest values both for diurnal pollen concentrations and annual pollen sums. The comparison of the data obtained by the volumetric method in the years 2003-2008 in Lublin and in Riga shows that there was a similar trend in the abundance of birch pollen (Fig. 2). In both sampling sites the largest amount of pollen grains was recorded in 2003. After exceptionally high pollen concentrations in 2003 both in Lublin and in Riga, the year 2004 can be considered to be "average", and the year 2005 "poor" in terms of annual pollen sums recorded. In both cities the years 2006 and 2008 belonged to the years with abundant birch pollen deposition. Very low pollen concentration values in the year 2007 in Riga may result from the incorrect operation of the Burkard sampler at that time (L. Kalnina - pers. communic.). In all the study years, annual pollen sums were higher in Lublin than in Riga (Fig. 2).

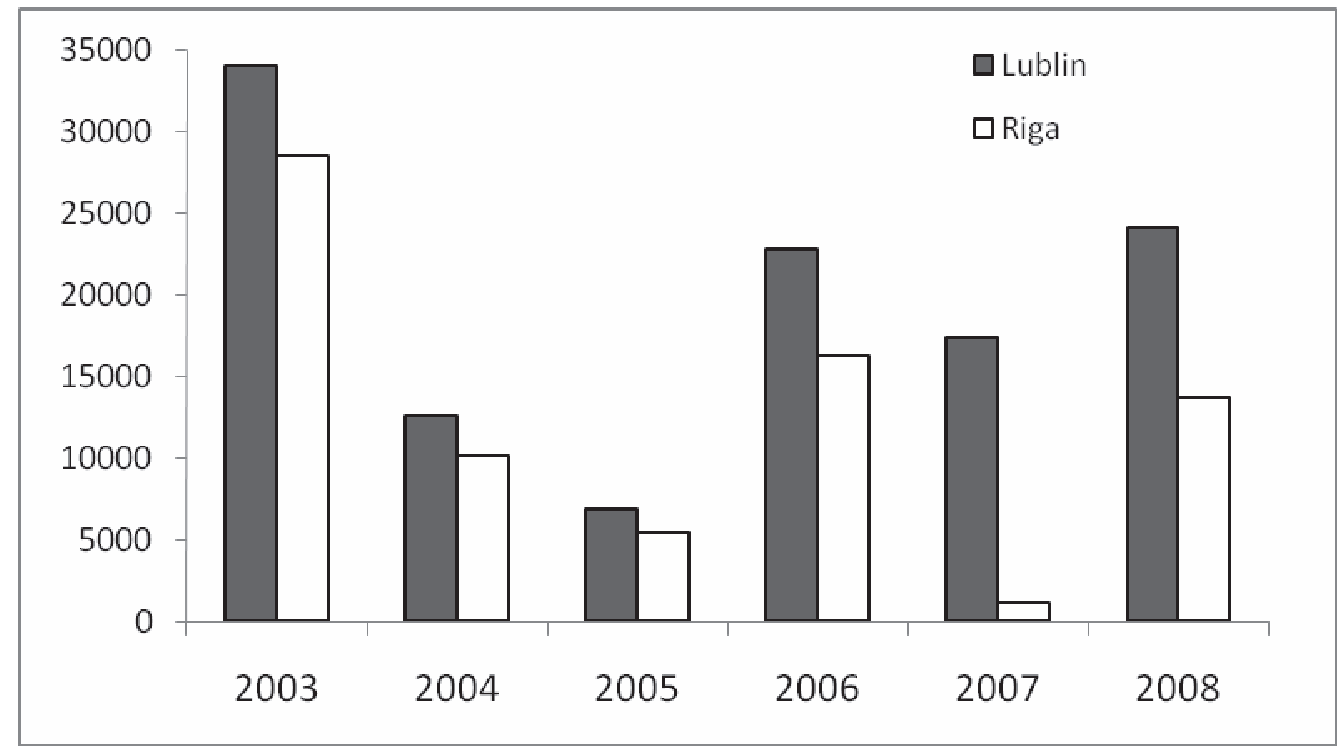

Fig. 2. Annual Betula pollen sum registered by volumetric air samplers in Riga and Lublin in the period $2003-2008$. 
Two peaks are usually noticeable on the curve illustrating the pollen season patterns at both sampling sites (Figs 3a, b). The birch pollen seasons started earlier in Lublin than in Riga by 6 days, on the average, and the largest difference was observed in the years
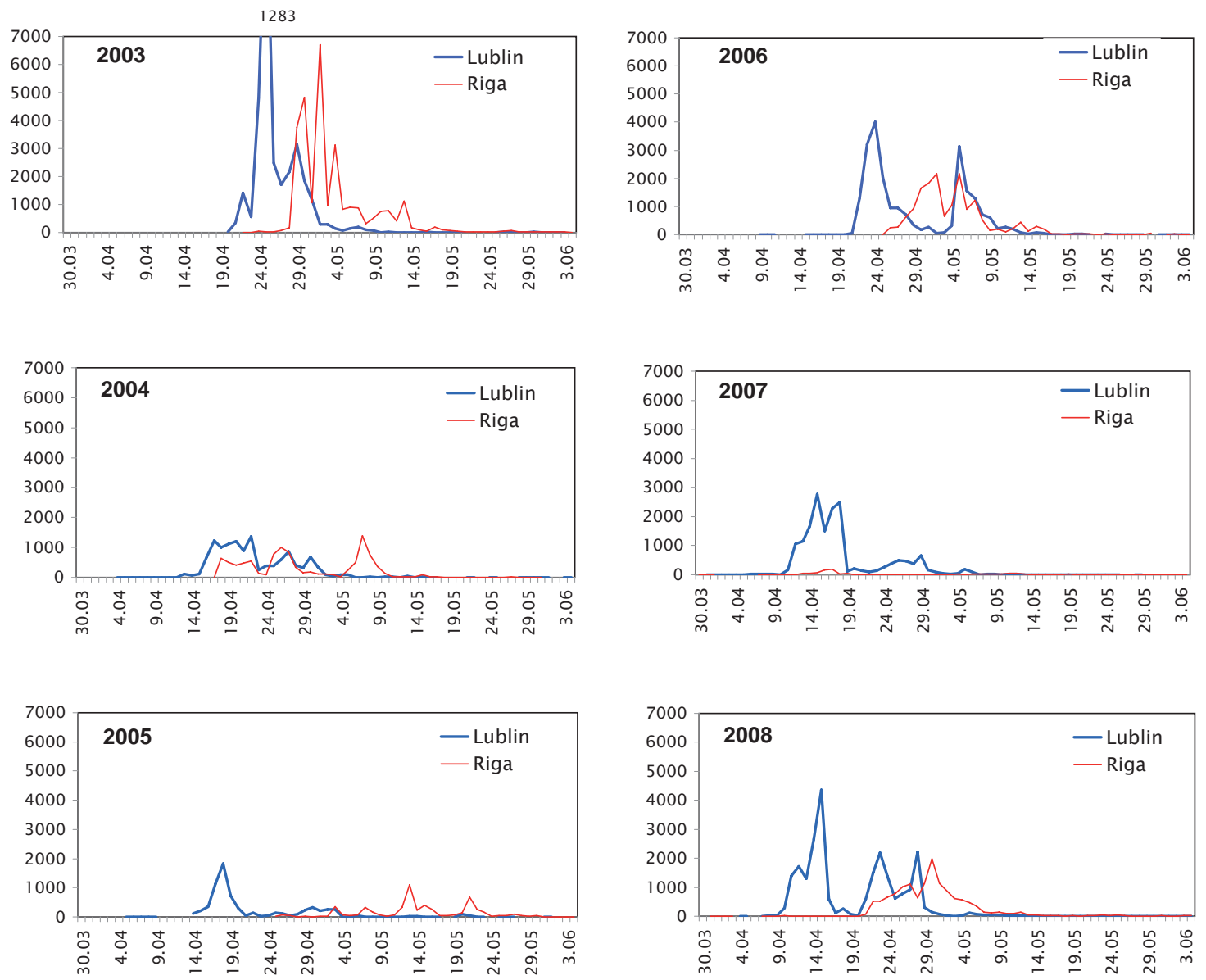

Fig. 3a. Dynamics of Betula pollen seasons in Lublin and in Riga, 2003-2008.

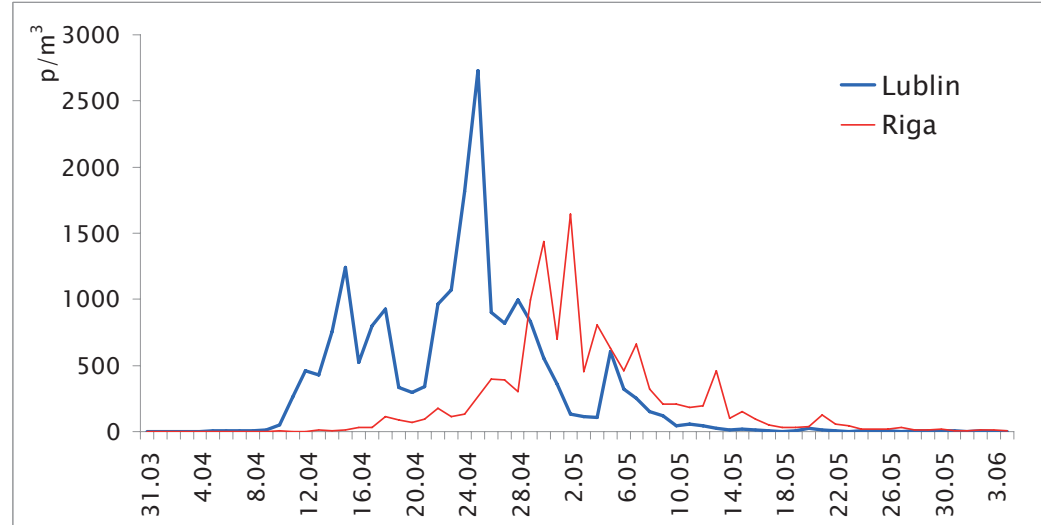

Fig. 3b. Comparison of Betula pollen seasons in Lublin and in Riga (average from 2003-2008 years). 
The greatest risk to people allergic to birch pollen in Lublin occurred in the first and second decades of April, whereas in Riga in the first half of May. Exceptionally, in 2007 the seasonal maxima were recorded in Riga on 17 April, but the pollen concentration value on that day was many times lower $(6-36$ times $)$ than in the other study years. The maximum pollen concentrations occurred in Lublin usually a short time after the onset of the pollen seasons. Under favourable weather conditions, a rapid increase in pollen concentration was observed at the start of the pollen season.
Over the six-year period, in Riga the seasonal maxima were, on the average, 11 days from the season start date. The largest difference in the dates of maximum pollen concentration in the trap sites compared was recorded in the year 2005. In this year, the start of the season in Riga (25 April 2005) was noted before the observed date of flowering of local birches, i.e. 2 May 2005 (L. Kalnina-pers. communic.).

Table 3

Characteristics of birch pollen seasons in Lublin and Riga.

\begin{tabular}{|c|c|c|c|c|c|c|c|c|c|c|c|c|}
\hline \multirow[t]{2}{*}{ Year } & \multicolumn{2}{|c|}{$\begin{array}{l}\text { Start of pollen } \\
\text { season }\end{array}$} & \multicolumn{2}{|c|}{ End of pollen } & \multicolumn{2}{|c|}{$\begin{array}{c}\text { Duration of } \\
\text { season (days) }\end{array}$} & \multicolumn{2}{|c|}{$\begin{array}{c}\text { Peak } \\
\text { concentration } \\
\text { (pollen grains } \\
/ \mathrm{m}^{3} / \text { day) }\end{array}$} & conce & ration & \multicolumn{2}{|c|}{$\begin{array}{l}\text { Annual pollen sum } \\
\text { in the season }\end{array}$} \\
\hline & Lublin & Riga & Lublin & Riga & Lublin & Riga & Lublin & Riga & Lublin & Riga & Lublin & Riga \\
\hline 2003 & 21.04 & 24.04 & 9.05 & 9.06 & 19 & 47 & 12832 & 6705 & 25.04 & 2.05 & 34095 & 28528 \\
\hline 2004 & 13.04 & 18.04 & 14.05 & 31.05 & 32 & 44 & 1367 & 1399 & 22.04 & 7.05 & 12608 & 10170 \\
\hline 2005 & 14.04 & 25.04 & 21.05 & 31.05 & 38 & 37 & 1815 & 1097 & 18.04 & 13.05 & 6943 & 5446 \\
\hline 2006 & 22.04 & 26.04 & 20.05 & 30.05 & 29 & 35 & 4015 & 2157 & 24.04 & 5.05 & 22809 & 16248 \\
\hline 2007 & 11.04 & 12.04 & 6.05 & 25.05 & 26 & 44 & 2762 & 186 & 15.04 & 17.04 & 17385 & 1143 \\
\hline 2008 & 10.04 & 21.04 & 12.05 & 4.06 & 33 & 45 & 4356 & 1969 & 15.04 & 30.04 & 24133 & 13781 \\
\hline
\end{tabular}

PMP method monitoring in SE Poland and Latvia

The analysis of mean annual birch pollen deposition showed that maximum deposition in Roztocze was in the years 2003 and 2008. The highest sums were then noted in the traps 6 and 7, located in agricultural wasteland. These were, respectively, 16265 and 23155 Betula pollen grains per $\mathrm{cm}^{2}$ (Fig. 4). In 2008, in addition to high deposition values in both the abovementioned traps, at the same time maxima were noted in the traps 4 and 8, which were respectively 10313 and 13621 Betula pollen grains per $\mathrm{cm}^{2}$. The year 2006 and, to a lesser extent, the years 2001 and 2005 belong to years of abundant pollen deposition. Definitely low values of Betula pollen sums were recorded in the years 1999, 2002 and 2004.
The biennial rhythm of abundant Betula deposition was noticeable in Roztocze only in the period 2001-2005.

The comparison of the data from the ten-year period common in Poland and Latvia, i.e. (1998-2007), for the four Tauber traps in Poland and the four traps in Latvia (Tables 4 and 5) shows that, unlike SE Poland where the year 2003 was clearly distinguished as a year with the highest birch pollen deposition values, in Latvia the highest annual sums were noted in 1999. It is reflected in all the sites in question (Tab. 6). Moreover, the year 2006 belonged to the abundant years in both countries. The "poor" years in Latvia include 2002, 2005 and 2007, since the sums recorded have values much below the 10-year means and they range between 1828 and 2765 grains $\mathrm{cm}^{-2}$ year $^{-1}$. Among the 




Fig. 4. Annual pollen sum of birch in four Tauber traps 4, 6, 7, 8 in Roztocze in the years 1998-2008. 
"poor" years, the respective values were in agreement with the data for SE Poland only for 2002, since the years 2005 and 2007 belonged to the years with high mean values for Betula pollen deposition in Roztocze. The very high values recorded in Taurene in 1998, but unconfirmed at the other two sites, can be accidental, e.g. they could have resulted from a portion of an inflorescence falling into the trap.

The analysis of the data from the Tauber traps in Latvia shows that in the years 2002-2005 the differ- ences in birch pollen abundance are poorly noticeable and that the biennial rhythm does not occur.

Comparison of the results of the studies carried out by the two methods

In Lublin aerobiological monitoring using the Lanzoni VPPS 2000 sampler was carried out since 2001. Hence, we have annual Betula pollen sums from eight seasons (2001-2008), which are also represented in the Tauber traps in Roztocze.

Table 4

Roztocze. Betula pollen deposition values for the Tauber traps and the percentage pollen index (values higher than the ten-year mean are bold-faced; * the absence of data in some years results from the destruction of the respective traps).

\begin{tabular}{ccccccccccc}
\hline & Trap 4 & PI & Trap 6 & PI & Trap 7 & PI & Trap 8 & $\begin{array}{c}\text { PI } \\
\begin{array}{c}\text { Pollen sum } \\
\text { from 2-4 } \\
\text { sites }\end{array}\end{array}$ Average \\
\hline 1998 & 3046 & 10.2 & 3715 & 5.1 & $*$ & $*$ & $*$ & $*$ & 6761 & 3381 \\
1999 & 1577 & 5.2 & 3188 & 4.3 & 4177 & 5.7 & 2907 & 7.4 & 11849 & 5925 \\
2000 & 3379 & 11.3 & $*$ & $*$ & $*$ & $*$ & 4059 & 10.3 & 7438 & 3719 \\
2001 & $\mathbf{4 3 9 1}$ & 14.7 & 7707 & 10.5 & $\mathbf{1 0 2 7 6}$ & 14.0 & $*$ & $*$ & 22374 & $\mathbf{7 4 5 8}$ \\
2002 & 1145 & 3.8 & 2799 & 3.8 & 3162 & 4.3 & 2567 & 6.5 & 9673 & 2419 \\
2003 & $\mathbf{6 0 9 0}$ & 20.4 & $\mathbf{1 6 2 6 5}$ & 22.2 & $\mathbf{2 3 1 5 5}$ & 31.5 & $\mathbf{9 8 6 8}$ & 25.1 & 55378 & $\mathbf{1 3 8 4 5}$ \\
2004 & 2622 & 8.8 & 4923 & 6.7 & 2278 & 3.1 & 3044 & 7.8 & 12867 & 3217 \\
2005 & $*$ & $*$ & 8354 & 11.4 & 9479 & 12.9 & $\mathbf{5 9 6 2}$ & 15.2 & 23795 & $\mathbf{7 9 3 2}$ \\
2006 & $\mathbf{4 0 9 8}$ & 13.8 & $\mathbf{1 3 8 2 0}$ & 18.8 & $\mathbf{1 3 1 1 6}$ & 17.8 & $\mathbf{7 7 6 8}$ & 19.8 & 38802 & $\mathbf{9 7 0 1}$ \\
2007 & 3449 & 11.6 & $\mathbf{1 2 5 5 8}$ & 17.1 & 7978 & 10.8 & 3064 & 7.8 & 27049 & 6762 \\
\hline Average & 3311 & & 8148 & & 9203 & & 4905 & & 21599 & 6436 \\
Sum & 29797 & $100 \%$ & $\mathbf{7 3 3 2 9}$ & $100 \%$ & 73621 & $100 \%$ & 39239 & $100 \%$ & 215986 & 64359 \\
\hline
\end{tabular}

Table 5

Latvia. Betula pollen deposition values for the Tauber traps and the percentage pollen index (values higher than the ten-year mean are bold-faced).

\begin{tabular}{|c|c|c|c|c|c|c|c|c|c|c|}
\hline Year & Taurene 1 & PI & Rucava1 & PI & $\begin{array}{c}\text { Teici Mire } \\
2\end{array}$ & PI & Marupe 2 & PI & $\begin{array}{c}\text { Pollen } \\
\text { sum of 3-4 } \\
\text { sites }\end{array}$ & Average \\
\hline 1998 & 16509 & 30.6 & 1390 & 10.5 & no data & & 1660 & 5.9 & 19559 & 6520 \\
\hline 1999 & 6683 & 12.4 & 1927 & 14.6 & 26383 & 44.5 & 5661 & 20.1 & 40654 & 10164 \\
\hline 2000 & 3565 & 6.6 & 2493 & 18.9 & 4619 & 7.8 & 1235 & 4.4 & 11912 & 2978 \\
\hline 2001 & 5035 & 9.3 & 1032 & 7.8 & 3111 & 5.2 & 4242 & 15 & 13420 & 3355 \\
\hline 2002 & 981 & 1.8 & 929 & 7 & 3777 & 6.4 & 1623 & 5.7 & 7310 & 1828 \\
\hline 2003 & 3859 & 7.2 & 1157 & 8.8 & 5447 & 9.2 & 1336 & 4.7 & 11799 & 2950 \\
\hline 2004 & 5574 & 10.3 & 1061 & 8 & 3637 & 6.1 & 1741 & 6.2 & 12013 & 3003 \\
\hline 2005 & 4537 & 8.4 & 1012 & 7.7 & 4145 & 7 & 1366 & 4.8 & 11060 & 2765 \\
\hline 2006 & 4432 & 8.2 & 1409 & 10.7 & 4166 & 7 & 7479 & 26.5 & 17486 & 4372 \\
\hline 2007 & 2790 & 5.2 & 800 & 6.1 & 3973 & 6.7 & 1887 & 6.7 & 9450 & 2363 \\
\hline Average & 5397 & & 1321 & & 6584 & & 2823 & & 15466 & 4030 \\
\hline Sum & 53965 & $100 \%$ & 13210 & $100 \%$ & 59258 & $100 \%$ & 28230 & $100 \%$ & 154663 & 40296 \\
\hline
\end{tabular}


Table 6

Annual Betula pollen grains sums in Roztocze (PMP method) and in Lublin (volumetric method) in the years 2001-2008 (values higher than the eight-year mean are bold-faced).

\begin{tabular}{ccccc}
\hline Year & $\begin{array}{c}\text { Roztocze } \\
\text { Average } \begin{array}{c}\text { Roztocze } \\
\text { per cm }{ }^{2}\end{array}\end{array}$ & $\begin{array}{c}\text { Lublin } \\
\text { The percentage pollen } \\
\text { index (PI) }\end{array}$ & $\begin{array}{c}\text { Lublin } \\
\text { Annual pollen sum per }{ }^{3} \\
\text { of air }\end{array}$ & $\begin{array}{c}\text { The percentage pollen } \\
\text { index (PI) }\end{array}$ \\
\hline 2001 & 7458 & 11.6 & 13670 & 10.0 \\
2002 & 2418 & 3.8 & 5354 & 3.9 \\
2003 & $\mathbf{1 3 8 4 5}$ & 21.6 & $\mathbf{3 4 1 3 4}$ & 24.9 \\
2004 & 3217 & 5.0 & 12647 & 9.2 \\
2005 & 7932 & 12.3 & 6951 & 5.1 \\
2006 & $\mathbf{9 7 0 1}$ & 15.1 & $\mathbf{2 2 8 9 9}$ & 16.7 \\
2007 & 6762 & 10.5 & $\mathbf{1 7 4 1 0}$ & 12.7 \\
2008 & $\mathbf{1 2 8 9 5}$ & 20.1 & $\mathbf{2 4 1 3 3}$ & 17.6 \\
\hline Average & 8028.5 & & 17149.7 & $100 \%$ \\
\hline
\end{tabular}

The most abundant Betula pollen deposition, both in Roztocze and in Lublin, was observed in the years 2003 and 2008 (Tab. 6). In addition, in Roztocze high sums were recorded in 2001, 2005 and 2006, whereas in Lublin in the years 2006 and 2007. There were definitely low values for Betula pollen in 2002 (the pollen index of 3.8-3.9\% for both sampling sites), in Roztocze additionally in 2004 (PI 5.0\%), and in Lublin in 2005 (PI 5.1\%). It can be seen that in the years 2004 and 2005 the Betula pollen index showed a reverse trend in Roztocze compared to Lublin.
An analogous comparison was made in Latvia, where the PMP site in Marupe near Riga, was selected for comparison with the aerobiological data from the Burkard sampler in Riga. The remaining sites in Latvia are located at much larger distances from Riga. The data series common for both sites comes from the period 2003-2007 (Tab. 7).

Table 7

Comparison of annual birch pollen sums from the Tauber trap in Marupe and the Burkard sampler in Riga (values higher than the five-year mean are bold-faced).

\begin{tabular}{ccccc}
\hline \multicolumn{2}{c}{ Marupe } & \multicolumn{2}{c}{ Riga } \\
Year & $\begin{array}{c}\text { Average annual } \\
\text { pollen sum per } \\
\mathrm{cm}^{2}\end{array}$ & $\begin{array}{c}\text { The percentage } \\
\text { pollen index (PI) }\end{array}$ & $\begin{array}{c}\text { Annual pollen } \\
\text { sum per } \mathrm{m}^{3} \\
\text { of air }\end{array}$ & $\begin{array}{c}\text { The percentage } \\
\text { pollen index (PI) }\end{array}$ \\
\hline 2003 & 1336 & 9.67 & $\mathbf{2 8 5 2 8}$ & 46.36 \\
2004 & 1741 & 12.61 & 10170 & 16.53 \\
2005 & 1366 & 9.89 & 5446 & 8.85 \\
2006 & $\mathbf{7 4 7 9}$ & 54.16 & $\mathbf{1 6 2 4 8}$ & 26.40 \\
2007 & 1887 & 13.67 & 1143 & 1.86 \\
\hline $\begin{array}{c}\text { Average } \\
\text { Sum }\end{array}$ & 2761.8 & & 12307.0 & $100 \%$ \\
\hline
\end{tabular}


In the case of these two sites, only the data from the year 2006 - a year of very abundant birch pollen production - are in clear agreement. Furthermore, the data for the two "poor" years - 2005 and 2007 - are in agreement. But a reverse trend occurred at both sites in 2003. The Burkard sampler in Riga recorded the maximum annual sum for the five-year period in question, whereas the Tauber trap in Marupe - the minimum annual sum over the five-year period.

\section{Meteorological data:}

The analysis of the Spearman's rank correlation coefficient $\left(\mathrm{r}_{\mathrm{s})}\right.$ ) between annual Betula pollen sum (6-year data) and mean air temperature in June, July and August in the year preceding pollen release as well as in January, February, March and April in the year of pollen emission in Lublin and Riga showed that the obtained results were not statistically significant (Tab. $8)$. However, it is worth mentioning that in the case of the months of the year preceding pollen release (JuneAugust), these were mostly positive values of the coefficient, whereas in the months of the year of pollen emission (January-April), these were negative values. The closest to statistically significant were January and February coefficients, but only in Poland.

Table 8

The Spearman's rank correlation coefficient values $\left(\mathrm{r}_{\mathrm{s}}\right.$ ) for mean temperature of chosen months and annual Betula pollen sum in Lublin and Riga in the common period 2003-2008 (explanations in the text).

\begin{tabular}{|c|c|c|c|c|c|c|c|}
\hline & \multicolumn{3}{|c|}{ Months of the year preceding pollen emission } & \multicolumn{4}{|c|}{ In the year of pollen emission } \\
\hline & June & July & August & January & February & March & April \\
\hline Lublin & 0.43 & -0.13 & 0.26 & -0.60 & $-0,59$ & -0.31 & -0.20 \\
\hline Riga & 0.31 & 0.43 & 0.49 & -0.03 & -0.26 & 0.09 & -0.26 \\
\hline
\end{tabular}

The similar results were obtained when analysing the correlation coefficients between mean temperature of selected months and annual Betula pollen sum in Lublin and in Roztocze over the period of 8 years (Tab. 9). The correlation coefficients are not statistically significant. In the months of the year preceding pollen emission (June-August), the coefficients have positive values, whereas in the months of the year of pollen emission (January-April) - negative values. However, those of January and February in Lublin are most close to correlation coefficient 0.643 ( $\mathrm{p}<0.05)$.

Table 9

The Spearman's rank correlation coefficient values $\left(r_{s}\right.$ ) for mean monthly air temperature and annual Betula pollen sum in Lublin and Roztocze in the common period 2001-2008 (explanations in the text).

\begin{tabular}{|c|c|c|c|c|c|c|c|}
\hline & \multicolumn{3}{|c|}{$\begin{array}{c}\text { Months of the year preceding pollen } \\
\text { emission }\end{array}$} & \multicolumn{4}{|c|}{ In the year of pollen emission } \\
\hline & June & July & August & January & February & March & April \\
\hline Lublin & 0.52 & 0.38 & 0.05 & -0.02 & -0.5 & -0.19 & -0.05 \\
\hline Roztocze & 0.36 & 0.05 & 0.21 & -0.02 & -0.63 & -0.50 & 0.12 \\
\hline
\end{tabular}

In the case of Roztocze, 11-year data series was used for the analysis of the correlation between annual Betula pollen sum and selected months (June, July,
August) of the preceding year as well as the months I-IV in the year of pollen emission. 


\section{Table 10}

The Spearman's rank correlation coefficient values $\left(\mathrm{r}_{\mathrm{s}}\right)$ for mean monthly air temperature and annual Betula pollen sum in Roztocze in the period 1998-2008 (explanations in the text).

\begin{tabular}{llcccccc}
\hline & \multicolumn{3}{c}{$\begin{array}{c}\text { Months of the year preceding pollen } \\
\text { emission }\end{array}$} & & \multicolumn{2}{c}{ In the year of pollen emission } \\
& June & July & August & January & February & March & April \\
\hline Roztocze & 0.12 & 0.18 & 0.41 & -0.01 & $\mathbf{- 0 . 5 9 *}$ & -0.45 & -0.23 \\
\hline
\end{tabular}

* correalation coefficient statistically significant $(\mathrm{p}<0.05)$

Table 10 shows that the correlation coefficient values were positive in the months June-August in the year preceding pollen emission and negative in the year of pollen emission. Among the analysed values of the correlation coefficient, it was statistically significant, with respect to air temperature in February in the year of pollen emission. The following correlation was observed: the lower temperature is in February in the year of pollen emission, the more abundant pollen shedding is.

\section{DISCUSSION}

The data for south-eastern Poland (Roztocze) and for Latvia are in complete agreement with regard to the trends obtained by both types of the sampling devices (i.e. the volumetric samplers and the Tauber traps) only in the year 2006, in which there was pollen abundance, and in the year 2002, which was a poor year in this respect. Moreover, the years 2003 and 2008 were recorded in the volumetric samplers in Riga and Lublin as the years with the highest annual birch pollen sums. This trend was also visible in the Tauber traps in south-eastern Poland. However, for unknown reasons, it was not reflected in the Tauber traps in Latvia. A reverse trend in annual sums was observed in 1999, which was an "abundant" year in Latvia, but a "poor" year in south-eastern Poland.

In the birch pollen season patterns in Lublin and Riga, large amounts of pollen were noted within a space of several days, what is in agreement with the observations from Finland, where the period of maximum pollen shedding lasted 2-3 days and at that time $70-80 \%$ of pollen grains was released from anthers (S u szka, 1979).

Two peaks on the curve of the pollen season patterns at both sampling sites, are probably attributable to pollen release by Betula pendula and later-flowering species (e.g. Betula pubescens).

In Lublin the onset of the Betula pollen season in the years 2003-2008 was between 10 and 22 May, whereas in Riga between 12 and 26 April. In the case of both cities, these differences are similar (12-14 days). Studies of other authors also show that in Germany differences between particular years, in terms of birch flowering dates, reached up to two weeks, which was a consequence of weather conditions prevailing in the last 30 days preceding the pollen release period (S u s z k a , 1979 and reference therein).

Significant differences in the values of annual Betula pollen sums in particular years result from varying pollen production conditioned by many factors. In spite of the fact that abundant years are most frequently followed by years of low or average birch pollen production (see S z c z e p a n e k, 1994), over the eight years concerned (2001-2008) the biennial rhythm of abundant birch pollen deposition was not clearly noticeable. The years 2005 and 2006 do not fit such a rhythm. The year of abundant Betula pollen deposition (2006) was also preceded by a quite abundant year of 2005, in terms of birch pollen release. The studies conducted earlier (1995-2000) in Lublin did not demonstrate the biennial rhythm of Betula pollen release (Piotrowska, 2006). These results differ from the observations of other authors who have found a biennial cycle of abundant pollen shedding of this taxon (Latałowa et al. 2002; S pieksma et al. 2003; Pidek et al. 2008).

But a comparison of annual Betula pollen sums recorded in Poland's cities distant from each other (Kraków, Poznań, Lublin, Szczecin, Rzeszów, Sosnowiec) in the years 2001-2005, prepared based on a collective work edited by WeryszkoChmielewska (2006), shows high consistency in terms of the occurrence of "abundant" and "poor" years on a wide regional scale (Pide k et al. 2008). This fact may suggest an essential role of the climatic factor in birch pollen production and release.

In the present paper, the analysis of mean monthly air temperature in the summer months of the year preceding pollen emission and in winter/spring (January-April) in the year of pollen release, ${ }_{2}$ potentially affecting birch pollen production and dispersion, has shown that in the case of Roztocze, where we have the 11-year pollen data series, low temperature in February may be of significance. This conclusion is in agree- 
ment with the interpretation of $\mathrm{van} d$ e $\mathrm{K} \mathrm{Knap}$ et al. (in print) who, after an analysis of long-term pollen monitoring data series in relation to climate data, suggest that in the case of some trees (among others, Betula) low temperatures in winter and drought may promote high pollen deposition in a given year. The impact of climate factors such as temperature, rainfall, spring frosts etc.on pollen production and release are still a matter of debate. There is an agreement however, that their effect may be inter-related ( $\mathrm{v}$ a $\mathrm{n} \mathrm{d}$ e $\mathrm{r}$ $\mathrm{K} \mathrm{n}$ a a $\mathrm{p}$ et al. in print). Birch, as a pioneer tree, may be less dependent in its reproduction on changing weather conditions, which is reflected by the similarity of obtained results in different climatic regions.

Based on long-term data series from Leiden and Derby, S p i e k s m a et al. (2003) found a significant increase in annual Betula pollen sums over the recent years. E mberlin et al. (1997) showed, based on 42-year studies in London, Derby and Cardiff, that the Betula pollen seasons start earlier, which is associated with higher cumulative temperatures in the period from January to March over the last years of the studies conducted by the abovementioned authors. In Lublin an early start of the birch pollen season (10-11 April) can also be observed over the last three years (2007-2009).

\section{Acknowledgments}

This study was partially financed by research funds for the years 2007-2010 as a research project N30409232/3590.

The results presented here address the scientific challenges described in COST Action ES0603 (EUPOL).

\section{REFERENCES}

Corden J., Millington W., Bailey J., Brookes M., Caulton E., Emberlin J., Mullins J., S impson C., Wood A., 2000. UK regional variations in Betula pollen (1993-1997). Aerobiologia, 16: 227-232.

Dahl A., Strandhede S. O., 1996. Predicting the intensity of the birch pollen season. Aerobiologia 12: 97-106

Emberlin J., S avage M., Woodman R., 1993. Annual variation in Betula pollen seasons in London 19611990. Grana, 32: 359-363.

Emberlin J., Mullins J., Cordon J., Millington W., B rooke M., S a vage M., J on es S., 1997. The trend to earlier birch pollen season in the UK, a biotic response to change in weather conditions? Grana, 36: 29-33.

Hi ck s S., H y värin en V. P., 1986. Sampling modern pollen deposition by means of 'Tauber traps': some considerations. Pollen et Spores, 28: 219-242.

Hicks S., A mmann B., Latałow a M., Pardoe H., Tinsley H., 1996. European Pollen Monitoring Program- me. Project Description and Guidelines. Oulu Univ. Press, Oulu, Finland.

Hicks S., Tinsley H., Pardoe H., Cundill P., 1999. European Pollen Monitoring Programme. Supplement to the Guidelines. Oulu Univ. Press, Oulu, Finland.

Kas zew ski B. M., 2008. Warunki klimatyczne Lubelszczyzny. Wydawnictwo Uniwersytetu Marii Curie-Skłodowskiej Lublin.

Latałowa M., Miętus M., Uruska A., 2002. Seasonal variation in the atmospheric Betula pollen count in Gdańsk (southern Baltic coast) in relation to meteorological parameters. Aerobiologia, 18: 33-43.

Levetin E., Rogers C. \& Hall S., 2000. Comparison of pollen sampling with a Burkard Spore Trap and Tauber Trap in a warm temperate climate. Grana, 39: 294-302.

Łomnicki A., 1995. Wprowadzenie do statystyki dla przyrodników. Państwowe Wydawnictwo Naukowe, Warszawa.

Marty n D., 2000. Klimaty kuli ziemskiej. Państwowe Wydawnictwo Naukowe, Warszawa.

Pidek I. A., Weryszko-Chmielewska E., Piotrowska K., 2006 Comparison of pollen concentration of selected tree taxa in Lublin and in the Roztocze region (SE Poland) - the results of three monitoring methods. Acta Agrobot. 59 (1): 355-364

Pidek I. A., Weryszko-Chmielewska E., Piotrows k a K., 2008. Czy istnieje dwuletni rytm obfitego pylenia brzozy i olszy? / Does a biennial rhythm of abundant birch and alder pollen release exist? Alergologia Immunologia, 5 (2): 61-65.

Piotrowska K., 2006. Kalendarz pyłkowy dla Lublina, 1995-2000. / Pollen calendar for Lublin, 1995-2000. Acta Agrobot. 59 (1): 529-538.

R ant a H., S o k ol C. \& Hi c k s S., 2007. Comparison of timeseries measurements between a volumetric air sampler and a Tauber pollen trap in the northern tree-line area of Fennoscandia. [In:] L. Kalnina, E. Luksevic (eds.) Abstracts. Pollen Monitoring Programme 6th International Meeting: 73-74, 3-9 June 2007, Jurmala, Latvia.

Rossi R. E., Monasterolo G., Monasterolo S., 2003. Detection of specific IgE antibodies in the sera of patients allergic to birch pollen using recombinant allergens Bet v 1, Bet v 2, Bet v 4: evaluation of different IgE reactivity profiles. Allergy, 58: 929-932.

Spieksma F.Th.M., Emberlin J. C., Hjelmroos M., Jäger S., Leuschner R. M., 1995. Atmospheric birch (Betula) pollen in Europe: trends and fluctuations in annual quantities and the starting dates of the season. Grana, 34: 51-61.

Spieksma F. Th. M., Corden J. M., Detandt M., Millington W. M., Nikkels H., Nolard N., Schoenmakers C. H. H., Wachter R., de Weger L. A., Willems R., Emberlin J., 2003. Quantitative trends in annual totals of five common airborne pollen types (Betula, Quercus, Poaceae, Urtica and Artemisia), at five pollen-monitoring stations in western Europe. Aerobiologia, 19: 171-184. 
S u szka B., 1979. Rozmnażanie generatywne. [In:] S. Białobok (ed.), Brzozy. Betula L. Nasze drzewa leśne, 7: 149-198, Państwowe Wydawnictwo Naukowe, Warszawa-Poznań (in Polish).

S z c z e p a n e k K., 1994. Pollen calendar for Cracow (southern Poland) 1982-1991. Aerobiologia, 10/1: 65-70

Tauber H., 1974. A statistic non-overload pollen collector. New Phytologist, 73: 359-369.

Van der Knaap W. O., van Leeuwen J. F. N., Svitavská-Svobodová H., Pidek I. A., Kvavadze E., Chichinadze M., Giesecke T., Kaszewski B. M., Oberli F., Kalnina L., Pardoe H. S., Tinner W., Ammann B., 2010. Annual pollen traps reveal high-frequency climate impact on pollen productivity in Europe and the Caucasus. Vegetation History and Archaeobotany (in print).

Weryszko-Chmielewska E., (ed.) 2006. Pyłek roślin w aeroplanktonie różnych regionów Polski. Wydawnictwo Wydziału Farmaceutycznego AM, Lublin (in Polish).

\section{Pylenie brzozy w Polsce i na Kotwie w świetle danych \\ z monitoringu aerobiologicznego i pułapek Taubera na tle średniej temperatury powietrza}

\section{Streszczenie}

Pyłek brzozy zawiera alergeny należące do najsilniej uczulających z grupy alergenów pyłku roślin. Celem prześledzenia, jak kształtuje się przebieg sezonów pyłkowych tego taksonu oraz sumy roczne pyłku w szerszej skali regionalnej, nawiązano współpracę z Uniwersytetem w Rydze (Łotwa). Z porównania wyników uzyskanych w latach 2003-2008 w Lub- linie i w Rydze przy zastosowaniu aparatów wolumetrycznych wynika, że istniała zbliżona tendencja w wielkości sum rocznych pyłku brzozy. Najwyższe sumy odnotowano na obydwu stanowiskach w roku 2003. We wszystkich latach badań w Lublinie rejestrowano więcej ziaren pyłku brzozy niż w Rydze, średnio o 7110. Sezony pyłkowe brzozy rozpoczynały się wcześniej w Lublinie niż w Rydze średnio o 6 dni i kończyły się wcześniej w Lublinie średnio o 18 dni. W Rydze sezony pyłkowe brzozy były dłuższe i sumy roczne pyłku mniejsze niż w Lublinie. W obydwu regionach, tj. w Polsce SE (rejon Roztocza) i Łotwie (rejon Marupe k. Rygi, Taurene, Teici i Rucava) istnieje ponadto seria danych pyłkowych uzyskanych z monitoringu rocznej depozycji pyłku do zmodyfikowanych pułapek Taubera. Pomiary te wykonywane są w ramach międzynarodowego projektu Pollen Monitoring Programme (http://pmp.oulu.fi) od 1998 roku. Aktualnie seria danych licząca 11 lat na Roztoczu i 10 lat na Łotwie pozwoliła prześledzić tendencje w występowaniu lat obfitego lub słabego opadu pyłku brzozy. Na Roztoczu maksimum depozycji pyłku Betula przypada na rok 2003, na Łotwie - w 1999 roku. Brak zgodności między Polską SE i Łotwą w zakresie tendencji w występowaniu lat obfitej depozycji pyłku Betula skłoniło do poszukiwania czynników klimatycznych odpowiedzialnych za zwiększoną produkcje pyłku brzozy. Analiza współczynników korelacji rang Spearmana pomiędzy rocznymi sumami pyłku Betula na Roztoczu i średnią temperaturą powietrza w czerw$\mathrm{cu}$, lipcu i sierpniu $\mathrm{w}$ roku poprzedzającym pylenie oraz wiosną (styczeń-kwiecień) w roku pylenia, wykazała istotną statystycznie negatywną korelację $\mathrm{z}$ temperaturą powietrza $\mathrm{w}$ lutym $\mathrm{w}$ roku pylenia. 